\title{
POTENSI LACTOBACILLUS YANG DIISOLASI DARI AIR SUSU IBU UNTUK MENCEGAH DIARE
}

\author{
[Potential of Lactobacillus Isolated from Breast Milk to Prevent Diarrheae]
}

\author{
Lilis Nuraida ${ }^{1,2)^{*}}$, Hana $\left.{ }^{1}, 2\right)$, Apriliana W. Hartanti2) dan Endang Prangdimurti1 ${ }^{1}$, \\ 1) South East Asian Food and Agriculture Science and Technology (SEAFAST) Center, Institut Pertanian Bogor, Bogor \\ 2) Departemen IImu dan Teknologi Pangan, Institut Pertanian Bogor, Bogor
}

Diterima 09 Desember 2011 / Disetujui 03 Desember 2012

\begin{abstract}
Some of Lactobacillus species isolated from breast milk are known to have antimicrobial activities, including against Escherichia coli. The aims of this study were to evaluate the antimicrobial activity of Lactobacillus species isolated from breast milk against enteropathogenic Escherichia coli strain K1.1 and the effectiveness of the Lactobacillus isolates to prevent diarrhea on rats (Sprague Dawley). The infective dose of E. coli K1.1 to induce diarrhea without causing death were also determined. Based on the antimicrobial activity there were three isolates of Lactobacillus that exhibited good inhibition againts E. coli K1.1, i.e. Lactobacillus rhamnosus R14, L. rhamnosus R23, and L. rhamnosus B16. Determination of E. coli infective dose showed that $10^{8} \mathrm{CFU}$ of E. coli K1.1 was sufficient to induce diarrhea on rat without causing death. The number of diarrhea rats and severity level in group treated with $L$. rhamnosus were lower than groups untreated with the Lactobacilli. This study showed that the three $L$. rhamnosus isolated from breast milk were able to prevent diarrhea due to infection of E. coli K1.1 when the Lactobacillus was regularly introduced prior to infection. L. rhamnosus R23 showed the best capabilities of preventing diarrhea in rats as compared to two other isolates of Lactobacillus. The incidence of diarrhea correlated with the number of lactobacilli in the feces. However when the period of diarrhea ceased, there were no difference in total lactobacilli and $E$. coli in the caecum, colon and feces between rats treated with L. rhamnosus and the control. This finding revealed the $L$. rhamnosus isolated from breast milk were potential for prevention of diarrhea when consumed regularly.
\end{abstract}

Keywords: antimicrobial activity, breast milk, diarrhea, E. coli, Lactobacillus rhamnosus

\begin{abstract}
ABSTRAK
Beberapa spesies Lactobacillus yang diisolasi dari air susu ibu (ASI) diketahui memiliki aktivitas antimikroba, termasuk terhadap Escherichia coli. Tujuan penelitian ini adalah mengevaluasi aktivitas antimikroba spesies Lactobacillus asal ASI terhadap Escherichia coli enteropatogenik strain K1.1 dan efektivitas Lactobacillus rhamnosus untuk mencegah diare pada tikus (Sprague Dawley). Dosis infeksi E. coli K1.1 yang dapat menginduksi diare tanpa menyebabkan kematian juga ditentukan. Berdasarkan aktivitas antimikroba, diperoleh tiga isolat Lactobacillus yang memiliki penghambatan yang baik terhadap E. coli K1.1, yaitu Lactobacillus rhamnosus R14, L. rhamnosus R23, dan L. rhamnosus B16. Penentuan dosis infeksi oleh E. coli menunjukkan bahwa sebanyak $10^{8}$ CFU E. coli K1.1 merupakan jumlah yang cukup untuk menginduksi diare pada tikus tanpa menyebabkan kematian. Jumlah tikus yang mengalami diare dan keparahannya pada tikus yang diberi $L$. rhamnosus lebih rendah dibandingkan dengan tikus yang tidak diberi $L$. rhamnosus namun diinfeksi dengan $E$. coli K1.1. Hasil penelitian ini menunjukkan bahwa tiga $L$. rhamnosus asal ASI mampu menghambat diare karena E. coli K1.1 jika Lactobacillus tersebut diberikan secara reguler sebelum terjadinya infeksi. $L$. rhamnosus R23 merupakan isolat dengan kemampuan yang paling baik dalam mencegah diare dibandingkan dengan dua isolat $L$. rhamnosus lainnya. Jumlah tikus yang mengalami diare berkorelasi dengan jumlah laktobasili di dalam feses. Akan tetapi jika periode diare telah berhenti, tidak ada perbedaan jumlah total laktobasili dan $E$. coli dalam sekum, kolon dan feses antara tikus yang diberi $L$. rhamnosus dan kontrol. Penelitian ini menunjukkan bahwa $L$. rhamnosus asal ASI berpotensi untuk mencegah diare jika dikonsumsi secara reguler.
\end{abstract}

Kata kunci: aktivitas antimikroba, air susu ibu, diare, E. coli, Lactobacillus rhamnosus

\section{PENDAHULUAN}

Diare dan gastroentritis karena infeksi tertentu menjadi urutan pertama penyebab rawat inap di rumah sakit di Indonesia, bahkan pada tahun 2006 penyakit ini menempati urutan ketiga penyakit utama penyebab kematian di rumah sakit di Indonesia setelah stroke dan perdarahan intrakranial (Depkes RI, 2008). Baik di negara berkembang, maupun di negara maju penyebab diare yang utama pada anak-anak adalah

*Korespondensi Penulis :

E-mail : lilis@seafast.org; lilis@nuraida.com; Hp: 081-1118583
Escherichia coli, Rotavirus, Salmonella spp., Shigella spp., Campylobacter jejuni, Entamoeba histolytica dan Giardia lamblia (Mandomando et al., 2007; Allen et al., 2010). E. coli enteropatogenik diketahui sebagai penyebab utama diare pada anak-anak berumur kurang dari dua tahun (Yatsuyanagi et al., 2003). Mikroba probiotik telah terbukti dapat mencegah atau menyembuhkan diare yang diakibatkan oleh infeksi patogen, virus maupun diare yang disebabkan oleh konsumsi antibiotik (Heyman dan Menard, 2002; de Vrese dan Marteau, 2007; Zanini et al., 2007). Penggunaan probiotik untuk mencegah atau mengobati diare merupakan fungsi probiotik yang paling umum diaplikasikan (Reid et al., 2003; de Vrese dan Marteau, 2007). 
Pemberian probiotik dapat mengurangi durasi dan keparahan diare (de Vrese dan Marteau, 2007; Allen et al., 2010).

Air susu ibu (ASI) telah dilaporkan oleh beberapa peneliti mengandung bakteri asam laktat yang berpotensi sebagai probiotik. Bifidobacterium longum adalah bakteri asam laktat (BAL) yang paling umum ditemukan dalam ASI, diikuti oleh $B$. animalis, B. bifidum, dan B. catenulatum (Gueimonde et al., 2007). Keberadaan laktobasili pada ASI yaitu $L$. gasseri, $L$. fermentum dan L. salivarius dilaporkan oleh Martin et al. (2005). Isolat ini berpotensi sebagai probiotik yang sama dengan strain yang telah digunakan secara konvensional (Martin et al., 2005). Hartanti (2010) menunjukkan dari 19 isolat BAL asal ASI yang memiliki ketahanan terhadap asam dan atau garam empedu, 5 isolat yaitu L. rhamnosus R14, R21, R23, B16 dan Lactobacillus $s p$. R25 dapat menurunkan E. coli K1.1 sebesar $>2 \log \mathrm{CFU} / \mathrm{mL}$ ketika ditumbuhkan secara bersama-sama pada media susu. Isolat Lactobacillus yang memiliki kemampuan menghambat pertumbuhan $E$. coli K.1. secara in vitro diharapkan mampu mencegah diare secara in vivo. Sebagaimana dipersyaratkan FAO/WHO (2002), dalam pengembangan bakteri probiotik, studi mengenai karakterisasi sifat fungsional bakteri asam laktat harus dilakukan pada hewan percobaan terlebih dahulu. Pemberian Lactobacillus casei I-5 dilaporkan efektif untuk mencegah infeksi karena E. coli pada tikus (Ishida-Fujii et al., 2007). Sementara itu Oyetayo (2004) menunjukkan tikus yang diberi Lactobacillus acidophilus dan diinfeksi $E$. coli, tidak mengalami diare seperti yang dialami oleh tikus yang hanya diberi E. coli. Penelitian yang dilakukan oleh Astawan et al. (2011) menunjukkan bahwa pemberian BAL yang diisolasi dari daging segar dapat menekan tingkat keparahan diare pada tikus akibat infeksi $E$. coli enteropatogenik. Pada penelitian tersebut paparan $E$. coli dilakukan selama tujuh hari berturutturut dengan jumlah $E$. coli sebanyak $10^{6} \mathrm{CFU} / \mathrm{mL}$ per hari. Penelitian ini bertujuan untuk mengetahui efektivitas isolat Lactobacillus asal ASI untuk mencegah diare pada tikus percobaan yang dinfeksi dengan $E$. coli K1.1. Pada penelitian ini infeksi oleh $E$. coli K1.1. dilakukan dengan paparan tunggal dengan dosis yang dapat menyebabkan diare. Paparan secara tunggal dilakukan untuk menghindari terjadinya imunitas pada tikus yang digunakan terhadap E. coli, karena paparan terhadap mikroorganisme yang berkali-kali dapat memicu terjadinya imunitas.

\section{BAHAN DAN METODE}

\section{Bahan}

Lima isolat Lactobacillus asal ASI yaitu L. rhamnosus (R14 R21, R23, dan B16) dan Lactobacillus sp. R25 dari koleksi SEAFAST Center IPB digunakan dalam penelitian ini. Bakteri yang digunakan untuk menginduksi diare adalah Escherichia coli enteropatogenik strain K1.1 yang berasal dari Laboratorium Bioteknologi Hewan dan Biomedis Pusat Penelitian Bioteknologi IPB dan tikus percobaan Sprague-Dawley jantan dari Pusat Studi Biofarmaka IPB. Bahan-bahan yang digunakan adalah bahan penyusun ransum modifikasi AIN-76 (AIN, 1977) dan media untuk uji mikrobiologi. Alat-alat yang dipergunakan dalam penelitian ini adalah peralatan untuk pengujian mikrobiologi dan pemeliharaan hewan percobaan.

\section{Pengujian aktivitas antimikroba Lactobacillus terhadap $E$. coli K1.1 secara in vitro}

Pengujian aktivitas antibakteri Lactobacillus terhadap E. coli K1.1 dilakukan dengan metode kontak. Kultur Lactobacillus dan E. coli disegarkan masing-masing ke dalam medium MRSB dan NB dan diinkubasi selama 24 jam. Isolat Lactobacillus dan kultur $E$. coli kemudian ditambahkan ke dalam tabung berisi larutan susu skim $10 \%$ sehingga susu mengandung $10^{8}$ $\mathrm{CFU} / \mathrm{mL}$ Lactobacillus dan $10^{5} \mathrm{CFU} / \mathrm{mL}$ E. coli, selanjutnya diinkubasi selama 24 jam pada suhu $37^{\circ} \mathrm{C}$. Susu dipilih sebagai medium dalam pengujian ini karena kedua bakteri dapat tumbuh dengan baik. Total Lactobacillus dan E. coli sebelum dan sesudah inkubasi dihitung dengan metode agar tuang masingmasing menggunakan media MRSA dan EMBA.

\section{Penentuan dosis $E$. coli K1.1 yang menyebabkan diare pada tikus (modifikasi Oyetayo, 2004)}

Protokol penggunaan tikus dalam penelitian ini telah mendapat persetujuan dari Komisi Etik Penelitian Kesehatan Badan Litbang Kesehatan Kemenkes (No. Lb.03.04/KE/6224 12010). Uji dosis dilakukan dengan pemberian E. coli pada beberapa konsentrasi sehingga tikus menjadi diare. Pada uji ini digunakan 20 ekor tikus yang terbagi dalam empat kelompok, yaitu satu kelompok kontrol yang hanya diberikan larutan fisiologis $(\mathrm{NaCl} 0,85 \%)$ dan tiga kelompok tikus yang diberi $E$. coli dengan berbagai konsentrasi $\left(10^{8}, 10^{7}\right.$ dan $\left.10^{6} \mathrm{CFU} / \mathrm{mL}\right)$. Sebelum pemberian $E$. coli tikus diadaptasikan dahulu selama dua minggu dengan pemberian ransum standar AIN-76 (AIN, 1977) yang telah dimodifikasi secara ad libitum dan air minum dalam kemasan. E. coli K1.1 ditumbuhkan pada medium NB selama 24 jam pada suhu $37^{\circ} \mathrm{C}$, kemudian disentrifuse dan pelet sel disuspensikan pada larutan garam fisiologis serta diencerkan sesuai dengan jumlah sel yang diinginkan. Pemberian suspensi $E$. coli sebanyak $1 \mathrm{~mL}$ sesuai dengan konsentrasi di atas dilakukan dengan cara dicekok (dengan alat sonde intragastrik). Pemberian E. coli hanya dilakukan sekali. Tikus kelompok kontrol dicekok dengan $1 \mathrm{~mL}$ larutan fisiologis $(\mathrm{NaCl}$ $0,85 \%$ ). Pengamatan feses tikus dilakukan sebelum pemberian E. coli $\mathrm{K} 1.1(\mathrm{HO} /$ hari ke 0$)$ dan setiap hari setelah pemberian $E$. coli sampai lima hari (H5/hari ke 5).

\section{Pengujian potensi isolat Lactobacillus asal ASI untuk men- cegah diare}

Pada uji aktivitas antidiare 30 ekor tikus dibagi menjadi lima kelompok, yaitu kelompok tikus yang tidak diintervensi $L$. rhamnosus maupun $E$. coli (kontrol negatif), kelompok tikus yang diintervensi $E$. coli tetapi tidak diintervensi isolat $L$. rhmnosus (kontrol $E$. coli), dan tiga kelompok tikus yang diintervensi $E$. coli dan $L$. rhamnosus sebagaimana disajikan pada Tabel 1. Jumlah $E$. coli yang diberikan adalah $10^{8} \mathrm{CFU}$ sesuai dengan dosis yang menyebabkan diare dan jumlah $L$. rhamnosus yang diberikan adalah $10^{\circ} \mathrm{CFU}$. Isolat Lactobacillus ditumbuhkan dalam MRSB pada suhu $37^{\circ} \mathrm{C}$ selama 24 jam, lalu disentrifus dan pelet sel disuspensikan dalam larutan fisiologis ( $\mathrm{NaCl} 0,85 \%)$. Pemberian L. rhamnosus dan E. coli dilakukan 
dengan cara dicekok. Tikus kelompok kontrol yang tidak diberi E. coli maupun Lactobacillus, dicekok dengan larutan fisiologis. Pengamatan dilakukan terhadap berat badan tikus (setiap dua hari), konsumsi ransum (setiap hari), konsistensi dan warna feses (setiap hari), serta jumlah total Lactobacillus dan E. coli pada feses sebelum diintervensi $L$. rahmnosus ( $\mathrm{H} 0 /$ hari ke 0 ), setelah intervensi $L$. rhamnosus pada $\mathrm{H} 1, \mathrm{H} 3, \mathrm{H} 7$ dan setelah intervensi $E$. coli pada $\mathrm{H} 8, \mathrm{H} 9, \mathrm{H} 10, \mathrm{H} 11$, dan $\mathrm{H} 12$. Pada $\mathrm{H} 12$, setelah terjadi penyembuhan diare, tikus diterminasi dengan teknik dislokasi tulang aksis (cervicalis dislocation). Jumlah total Lactobacillus dan E. coli pada kolon dan sekum tikus selanjutnya dihitung dan analisis dengan program SPSS 13,0 dan uji beda lanjut dengan uji Duncan. Pengamatan kolon tikus dengan menggunakan SEM (Scanning Electron Microscope) dilakukan pada pengamatan $\mathrm{H} 12$.

\section{HASIL DAN PEMBAHASAN}

\section{Aktivitas antimikroba isolat Lactobacillus terhadap $E$. coli K.1.1 secara in vitro}

Hasil pengujian aktivitas antimikroba isolat Lactobacillus terhadap $E$. coli K1.1 dengan menggunakan metode kontak menunjukkan bahwa tiga isolat yaitu $L$. rhamnosus R14, $L$. rhamnosus R23, dan L. rhamnosus B16 (Gambar 1) memiliki peng-hambatan lebih tinggi atau menurunkan jumlah $E$. coli yang lebih besar dari 2 isolat lainnya. Hasil penelitian ini menunjukkan bahwa sifat antimikroba tergantung pada strain. $\mathrm{Hal}$ yang sama terjadi pada Lactobacillus asal ASI yang dilakukan oleh peneliti terdahulu (Olivares et al., 2006). Ketiga isolat tersebut selanjutnya digunakan untuk pengujian secara in vivo potensi Lactobacillus rhamnosus asal ASI sebagai antidiare.

\section{Dosis $E$. coli K1.1 yang menyebabkan diare pada tikus}

Hasil pengujian menunjukkan pemberian dosis $E$. coli K1.1 sebesar $10^{8}$ CFU menyebabkan 4 dari 5 tikus diare sehari setelah pemberian $E$. coli (Tabel 2). Semakin menurun dosis yang diberikan jumlah tikus yang diare pada hari pertama semakin kecil. Pada umumnya tikus mengalami diare selama 2 hari, lalu sembuh pada hari-hari berikutnya. Pada pemberian dosis $10^{6} \mathrm{CFU}$, terjadi keterlambatan terjadinya diare yang terlihat dari tidak adanya tikus yang diare sehari setelah pemberian E. coli. Pada hari kedua baru terjadi diare pada 1 dari 5 tikus, lalu meningkat menjadi 3 dan turun kembali pada hari-hari berikutnya yang menunjukkan terjadinya penyembuhan. Pola yang tidak teratur diamati pada pemberian dosis $10^{7} \mathrm{CFU}$. Untuk penelitian pada tahap selanjutnya digunakan dosis $10^{8} \mathrm{CFU}$ yang merupakan dosis $E$. coli K1.1 yang dapat menimbulkan diare terbanyak pada tikus tanpa menimbulkan kematian.

Dosis E. coli K1.1 sebesar $10^{6}$ CFU belum menyebabkan diare dalam waktu sehari setelah pemberian $E$. coli. Diare baru terjadi ketika digunakan dosis $10^{7}$ atau $10^{8} \mathrm{CFU}$. Dosis tinggi yang dibutuhkan pada penelitian ini kemungkinan disebabkan karena tikus yang digunakan pada penelitian ini bukan tikus bebas mikroba (germ free) atau gnotobiotik, yaitu hewan yang mengandung mikroba yang diketahui jenisnya atau spesiesnya (Zhang et al., 2008). Respon imun terhadap infeksi pada hewan gnotobiotik lebih rendah daripada hewan yang dipelihara secara konvensional (Zhang et al., 2008). Tikus yang digunakan dalam penelitian ini adalah tikus yang dipelihara secara konvensional sehingga kemungkinan sudah terpapar berbagai jenis bakteri, sebagai akibatnya dosis untuk menyebabkan sakit menjadi lebih tinggi. Ishida-Fujii et al. (2007) menggunakan dosis tinggi yaitu $3 \times 10^{7}$ - $1 \times 10^{8}$ sel $E$. coli untuk pengujian pencegahan infeksi $E$. coli pada tikus oleh Lactobacillus casei I-5.

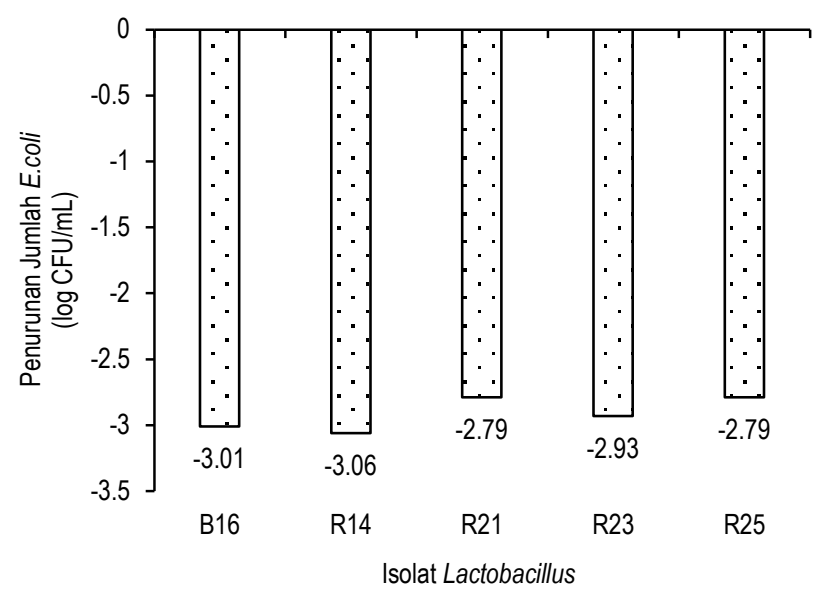

Gambar 1. Penurunan jumlah E. coli K1.1 setelah dikompetisikan dengan 5 isolat Lactobacillus asal ASI secara in vitro

Tabel 2. Hasil pengujian dosis E. coli K1.1 yang menyebabkan tikus diare

\begin{tabular}{|c|c|c|c|c|c|}
\hline \multirow{2}{*}{$\begin{array}{l}\text { Dosis } E \text {. coli } \\
\text { K1.1 per hari }\end{array}$} & \multicolumn{5}{|c|}{$\begin{array}{l}\text { Jumlah Tikus Diare/Jumlah Seluruh Tikus } \\
\text { Setelah Pemberian E. coli K1.1 Selama: }\end{array}$} \\
\hline & 1 Hari & 2 hari & 3 Hari & 4 Hari & 5 hari \\
\hline Kontrol & $0 / 5$ & $0 / 5$ & $0 / 5$ & $0 / 5$ & $0 / 5$ \\
\hline $10^{6} \mathrm{CFU}$ & $0 / 5$ & $1 / 5$ & $3 / 5$ & $2 / 5$ & $1 / 5$ \\
\hline $10^{7} \mathrm{CFU}$ & $2 / 5$ & $0 / 5$ & $1 / 5$ & $0 / 5$ & $2 / 5$ \\
\hline $10^{8} \mathrm{CFU}$ & $4 / 5$ & $2 / 5$ & $0 / 5$ & $0 / 5$ & $0 / 5$ \\
\hline
\end{tabular}

Tabel 1. Perlakuan tikus pada pengujian potensi isolat L. rhamnosus asal ASI untuk mencegah diare karena E. coli K1.1

\begin{tabular}{|c|c|c|c|c|}
\hline \multirow[b]{2}{*}{ Kelompok Perlakuan } & \multicolumn{4}{|c|}{ Periode (Hari ke) } \\
\hline & $\begin{array}{c}\text { Adaptasi* } \\
(\mathrm{H}-14 \text { s.d. H0) }\end{array}$ & $\begin{array}{l}\text { Perlakuan } 1 \\
\text { (H1 s.d. H6) }\end{array}$ & $\begin{array}{c}\text { Perlakuan } 2 \\
(\mathrm{H} 7)\end{array}$ & $\begin{array}{l}\text { Perlakuan } 3 \\
\text { (H8 s.d. H12) }\end{array}$ \\
\hline Kontrol negatif & \multirow{5}{*}{ ransum standar } & ransum standar & ransum standar & ransum standar \\
\hline Kontrol E. coli & & \multirow{4}{*}{$\begin{array}{l}\text { ransum standar }+L \text {. } \\
\text { rhamnosus } 10^{9} \mathrm{CFU}\end{array}$} & ransum standar + E. coli K1.1.108 $\mathrm{CFU}$ & \multirow{4}{*}{$\begin{array}{l}\text { ransum standar }+L \\
\text { rhamnosus } 10^{9} \mathrm{CFU}\end{array}$} \\
\hline L. rhamnosus R14 & & & ransum standar + E. coli K1.1.108 CFU + L. & \\
\hline L. rhamnosus $\mathrm{R} 23$ & & & rhamnosus $10^{9} \mathrm{CFU}$ & \\
\hline L. rhamnosus B16 & & & & \\
\hline
\end{tabular}


Pengaruh pemberian asupan isolat Lactobacillus asal ASI terhadap kejadian diare akibat infeksi $E$. coli K1.1

Selama masa pengujian aktivitas antidiare berat badan tikus terus meningkat dan tidak terjadi penurunan berat badan walaupun sudah diinfeksi dengan $E$. coli K1.1. Berdasarkan penampakan feses, diare yang ditimbulkan tidak mengakibatkan tikus banyak kekurangan cairan, sehingga berat badan tikus masih mengalami peningkatan selama perlakuan.

Hasil pengujian (Tabel 3) menunjukkan bahwa ketiga isolat L. rhamnosus memiliki kemampuan untuk mencegah diare. Hal ini terlihat dari jumlah tikus yang mengalami diare, tingkat keparahan diare, dan waktu munculnya diare tersebut. Diare pada tikus kelompok kontrol $E$. coli terjadi segera setelah pemberian $E$. coli K1.1 (tiga dari enam tikus mengalami diare pada H8). Sedangkan diare pada tikus kelompok $L$. rhamnosus R14 baru terjadi pada $\mathrm{H} 10$ (satu dari enam tikus mengalami diare pada hari ke 10). Kelompok tikus yang diberi L. rhamnosus B16 juga mengalami diare segera setelah diberi E. coli K1.1 (H8), akan tetapi jumlah tikus yang diare lebih sedikit (dua dari enam tikus). Disamping itu, keparahan diare antara kelompok kontro $E$. coli dengan kelompok yang diberi $L$. rhamnosus berbeda. Tikus kelompok kontrol $E$. coli mengalami diare yang lebih parah, yaitu ditunjukkan dengan penampakan feses yang tidak berbentuk, sangat lembek dan berlendir (tipe 6 berdasarkan Bristol Stool Chart (Lewis dan Heaton, 1997)). Sedangkan tikus yang diberi $L$. rhamnosus R14 dan $L$. rhamnosus B16 mengalami diare yang lebih ringan, yaitu fesesnya lembek namun masih berbentuk (tipe 5 berdasarkan Bristol Stool Chart (Lewis dan Heaton, 1997)). Pada umumnya tikus menderita diare hanya selama 1-2 hari (Tabel 3), sehingga setelah 5 hari dari pemberian $E$. coli $(\mathrm{H} 12)$, tidak ada lagi tikus yang diare. Kelompok tikus yang diberi isolat $L$. rhamnosus R23 tidak mengalami diare selama pengujian berlangsung, Hal ini menunjukkan bahwa $L$. rhamnosus R23 memiliki kemampuan yang paling baik dalam mencegah diare. Kemampuan probiotik untuk mencegah diare karena bakteri atau virus tergantung pada strain dan dosis yang digunakan (Allen et al., 2010).

E. coli enteropatogenik memiliki plasmid yang mengkode pembentukan pili untuk penempelan bakteri pada sel epitel dan produksi protein yang diperlukan untuk menyebabkan luka (lesion) (Nguyen et al., 2006). Budiarti dan Mubarik (2007) menunjukkan $E$. coli K1.1 dapat menghasilkan enzim protease ekstra seluler yang dapat mendegradasi mucin sehingga dapat melekat pada sel epitel usus dan menimbulkan diare pada inang. Michail dan Abernathy (2002) menguji efek penghambatan L. plantarum terhadap E. coli dan respon sekretori sel epitel usus menggunakan model sel Caco-2. Paparan $L$. plantarum diberikan sebelum, bersamaan dan setelah infeksi $E$. coli.

Hasil yang diperoleh menunjukkan bahwa $L$. plantarum mengurangi perubahan respon sekretori terhadap infeksi $E$. coli, kemungkinan melalui penghambatan pengikatan $E$. coli enteropatogenik pada sel epitel. L. plantarum juga mengurangi pengikatan E. coli pada sel Caco-2. Penelitian lebih lanjut menunjukkan bahwa $L$. plantarum menghambat migrasi neutrofil sehingga menghambat respon inflamasi karena infeksi $E$. coli enteropatogenik (Michail dan Abernity, 2003). Akan tetapi efek ini hanya dapat terjadi jika probiotik tersebut telah diberikan sebelum infeksi E. coli (preventif). Sherman et al. (2005) menunjukkan $L$. acidophilus dan $L$. rhamnosus mencegah terjadinya luka pada sel epitel karena infeksi $E$. coli.

\section{Pengaruh pemberian asupan isolat Lactobacillus asal ASI dan $E$. coli K1.1 terhadap jumlah $E$. coli dalam feses}

Jumlah $E$. coli pada tikus selama pengujian disajikan pada Gambar 2. Pada kelompok kontrol negatif (selama pengujian seluruh tikus hanya diberikan larutan fisiologis), jumlah $E$. coli cenderung stabil. Kelompok kontrol E. coli (kelompok tikus yang diberi $E$. coli $\mathrm{K} 1.1$ tanpa diberi $L$. rhamnosus) menunjukkan kenaikan jumlah $E$. coli pada feses yang cukup tinggi, yaitu 0,83 $\log$ CFU/g feses (Tabel 4) sehari setelah pemberian E. coli (pengamatan $\mathrm{H} 8$ ). Hal ini berkorelasi dengan jumlah tikus yang mengalami diare pada pengamatan $\mathrm{H} 8$ yang berjumlah 3 ekor dari 6 ekor tikus (Tabel 4). Penelitian Oyetayo et al. (2003) menunjukkan pemberian $L$. acidophillus dan $L$. casei yang diisolasi dari susu sapi selama 3 hari berturut-turut, menurunkan jumlah enterobacteriacea dalam feses tikus. Pemberian $L$. acidophillus juga mencegah terjadinya diare pada tikus (Oyetayo, 2004).

Tabel 3. Pengaruh pemberian isolat Lactobacillus asal ASI terhadap kejadian diare akibat infeksi E. coli K1.1

\begin{tabular}{|c|c|c|c|c|c|c|c|c|c|}
\hline \multirow{3}{*}{ Kelompok Tikus } & \multicolumn{9}{|c|}{ Jumlah Tikus Diare/Jumlah Seluruh Tikus } \\
\hline & \multicolumn{9}{|c|}{ Pemberian Asupan Lactobacillus (Hari ke) } \\
\hline & $\mathrm{HO}$ & $\mathrm{H} 1$ & $\mathrm{H} 3$ & $\mathrm{H} 7$ & $\mathrm{H} 8$ & $\mathrm{H} 9$ & $\mathrm{H} 10$ & $\mathrm{H} 11$ & $\mathrm{H} 12$ \\
\hline Kontrol negatif & $0 / 6$ & $0 / 6$ & $0 / 6$ & $0 / 6$ & $0 / 6$ & $0 / 6$ & $0 / 6$ & $0 / 6$ & $0 / 6$ \\
\hline Kontrol E. coli & $0 / 6$ & $0 / 6$ & $0 / 6$ & $0 / 6$ & $3 / 6$ (a) & $1 / 6(\mathrm{a})$ & $0 / 6$ & $0 / 6$ & $0 / 6$ \\
\hline L. rhamnosus R14 & $0 / 6$ & $0 / 6$ & $0 / 6$ & $0 / 6$ & $0 / 6$ & $0 / 6$ & $1 / 6^{(b)}$ & $2 / 6^{(b)}$ & $0 / 6$ \\
\hline L. rhamnosus R23 & $0 / 6$ & $0 / 6$ & $0 / 6$ & $0 / 6$ & $0 / 6$ & $0 / 6$ & $0 / 6$ & $0 / 6$ & $0 / 6$ \\
\hline L. rhamnosus B16 & $0 / 6$ & $0 / 6$ & $0 / 6$ & $0 / 6$ & $2 / 6^{(b)}$ & $0 / 6$ & $0 / 6$ & $0 / 6$ & $0 / 6$ \\
\hline
\end{tabular}

Keterangan :

(a) = feses tidak berbentuk, berwarna agak kecoklatan, sangat lembek, berlendir (tipe 6 berdasarkan Bristol Stool Chart)

(b) = feses berbentuk bulat atau lonjong, berwarna hitam, tidak padat, lembek (tipe 5 berdasarkan Bristol Stool Chart) 
Versi Online:

http://journal.ipb.ac.id/index.php/jtip

DOI: 10.6066/jtip.2012.23.2.158

Hasil Penelitian

J. Teknol. dan Industri Pangan, Vol. XXIII No. 2 Th. 2012

Tabel 4. Jumlah tikus diare dan perubahan jumlah E. coli dan Lactobacillus pada feses setelah pemberian E. coli K1.1

\begin{tabular}{|c|c|c|c|c|c|c|c|c|c|c|c|c|c|c|c|}
\hline \multirow{2}{*}{ Kelompok Perlakuan } & \multicolumn{3}{|c|}{ Setelah 1 Hari $(\mathrm{H} 8)$} & \multicolumn{3}{|c|}{ Setelah 2 Hari (H9) } & \multicolumn{3}{|c|}{ Setelah 3 Hari $(\mathrm{H} 10)$} & \multicolumn{3}{|c|}{ Setelah 4 Hari (H11) } & \multicolumn{3}{|c|}{ Setelah 5 Hari $(\mathrm{H} 12)$} \\
\hline & FD & $\Delta \mathrm{EC}$ & $\Delta \mathrm{LB}$ & FD & $\Delta \mathrm{EC}$ & $\Delta \mathrm{LB}$ & FD & $\Delta \mathrm{EC}$ & $\Delta \mathrm{LB}$ & FD & $\Delta \mathrm{EC}$ & $\Delta \mathrm{LB}$ & FD & $\Delta \mathrm{EC}$ & $\Delta \mathrm{LB}$ \\
\hline Kontrol negatif & $0 / 6$ & 0,21 & 0,16 & $0 / 6$ & 0,02 & 0,20 & $0 / 6$ & $-0,58$ & $-0,16$ & $0 / 6$ & $-0,35$ & $-0,47$ & $0 / 6$ & $-0,58$ & $-0,53$ \\
\hline Kontrol E. coli & $3 / 6^{(a)}$ & 0,83 & $-1,29$ & $1 / 6^{(a)}$ & 0,59 & $-1,71$ & $0 / 6$ & 0,32 & $-1,42$ & $0 / 6$ & 0,11 & $-0,97$ & $0 / 6$ & $-0,4$ & $-0,88$ \\
\hline L. rhamnosus R14 & $0 / 6$ & 0,44 & $-0,07$ & $0 / 6$ & 0,43 & 0,31 & $1 / 6^{(b)}$ & $-0,42$ & 0,39 & $2 / 6^{(b)}$ & $-0,12$ & 0,19 & $0 / 6$ & $-0,22$ & 0,34 \\
\hline L. rhamnosus R23 & $0 / 6$ & $-0,13$ & $-0,09$ & $0 / 6$ & $-0,57$ & 0,38 & $0 / 6$ & $-1,00$ & $-0,19$ & $0 / 6$ & $-1,3$ & $-0,10$ & $0 / 6$ & $-1,53$ & 0,30 \\
\hline L. rhamnosus B16 & $2 / 6^{(b)}$ & 0,36 & $-0,07$ & $0 / 6$ & 0,43 & 0,07 & $0 / 6$ & 0,11 & $-0,11$ & $0 / 6$ & $-0,47$ & $-0,15$ & $0 / 6$ & $-0,52$ & 0,08 \\
\hline
\end{tabular}

Keterangan :

$\mathrm{FD} \quad=$ frekuensi kejadian diare (jumlah tikus diare/jumlah seluruh tikus)

$\Delta \mathrm{EC}=$ selisih jumlah $E$. coli dalam feses (log CFU/g) pada hari tersebut dibandingkan dengan sebelum paparan terhadap $E$. coli K1.1 (H7)

$\Delta \mathrm{LB}=$ selisih jumlah Lactobacillus dalam feses (log CFU/g) pada hari tersebut dibandingkan dengan sebelum paparan terhadap E. coli K1.1 (H7)

(a) = feses tidak berbentuk, berwarna agak kecoklatan, sangat lembek, berlendir (tipe 6 berdasarkan Bristol Stool Chart)

(b) = feses berbentuk bulat atau lonjong, berwarna hitam, tidak padat, lembek (tipe 5 berdasarkan Bristol Stool Chart)

Pada kelompok tikus yang diberi L. rhamnosus R14 menunjukkan sedikit kenaikan jumlah $E$. coli sehari setelah pemberian E. coli K1.1, yaitu sebesar 0,44 log CFU/g feses (Tabel 4), tetapi kemudian turun kembali setelah 3 hari (pada pengamatan $\mathrm{H} 10$ ). Hal ini berkorelasi dengan tidak adanya tikus yang mengalami diare pada pengamatan $\mathrm{H} 8$ meskipun pada pada $\mathrm{H} 10$ dan $\mathrm{H} 11$ terdapat masing-masing seekor dan 2 ekor tikus yang mengalami diare, tetapi gejala diare yang tampak hanya feses yang sedikit lembek dengan bentuk normal atau tipe 5 berdasarkan Bristol Stool Chart (Tabel 4). Pada kelompok tikus yang diberi L. rhamnosus R23 menunjukkan sedikit penurunan jumlah $E$. coli sehari setelah pemberian $E$. coli K1.1 (pengamatan $\mathrm{H} 8$ ), yaitu turun sebesar $0,13 \mathrm{log} \mathrm{CFU} / \mathrm{g}$ feses (Tabel 4) dan terus mengalami penurunan sampai H12. Hal ini berkorelasi dengan tidak adanya satu ekor tikuspun yang mengalami diare setelah diberi $E$. coli K1.1. Pada kelompok tikus yang diberi asupan L. rhamnosus B16 menunjukkan sedikit kenaikan jumlah $E$. coli sehari setelah intervensi $E$. coli K1.1 (pengamatan $\mathrm{H} 8$ ), yaitu sebesar 0,36 log CFU/g feses (Tabel 4), tetapi kemudian mengalami penurunan hingga $\mathrm{H} 12$. Hal ini berkorelasi dengan adanya 2 ekor tikus yang mengalami diare pada H8 tetapi gejala diare yang tampak hanya feses yang sedikit lembek dengan bentuk normal atau tipe 5 berdasarkan Bristol Stool Chart sama seperti diare pada kelompok tikus yang diberi asupan L. rhamnosus R14 (Tabel 4). Pada H12 atau setelah 5 hari pemberian $E$. coli $\mathrm{K} 1.1$, tidak ada lagi tikus yang mengalami diare. Pada $\mathrm{H} 12$ jumlah $E$. coli pada feses tikus berkisar antara 7,07-7,90 log CFU/g feses, dengan jumlah $E$. coli yang lebih rendah pada kelompok tikus yang diberi $L$. rhamnosus (Gambar 2), yaitu 7,07-7,35 log CFU/g feses, dibandingkan dengan kedua kontrol yaitu sebesar 7,78 dan 7,90 $\log$ CFU/g feses.

Pengaruh pemberian asupan isolat Lactobacillus asal ASI dan E. coli K1.1 terhadap jumlah Lactobacillus dalam feses tikus

Jumlah Lactobacillus pada tikus selama pengujian disajikan pada Gambar 3. Pada kelompok kontrol negatif jumlah Lactobacillus cenderung stabil, sedangkan pada kelompok kontrol E. coli terjadi penurunan jumlah Lactobacillus yang sangat drastis setelah pemberian $E$. coli $\mathrm{K} 1.1$, yaitu sebesar $1,29 \log \mathrm{CFU} / \mathrm{g}$ feses pada pengamatan $\mathrm{H} 8$ dan turun sebesar 1,71 log CFU/g pada H9 (Tabel 4), meskipun kemudian mengalami kenaikan kembali hingga $\mathrm{H} 12$ dimana tikus telah sembuh dari diare (Gambar 3 dan Tabel 4). Hal ini menunjukkan bahwa pemberian $E$. coli $10^{8} \mathrm{CFU}$ pada tikus menyebabkan terjadinya gangguan keseimbangan mikrobiota usus ditandai dengan penurunan jumlah Lactobacillus karena terjadinya kompetisi dalam kolonisasi sel epitel usus pada tikus yang tidak diberi asupan L. rhamnosus.

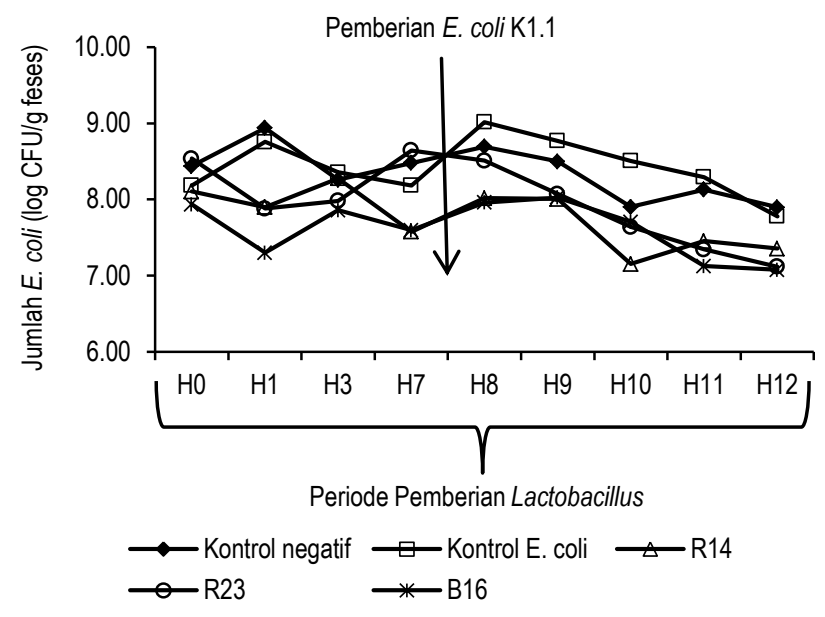

Gambar 2. Jumlah E. coli pada feses tikus pada kelompok kontrol negatif, kontrol $E$. coli, dan kelompok tikus yang diberi $L$. rhamnosus $\mathrm{R} 14$, L. rhamnosus $\mathrm{R} 23$, dan $L$. rhamnosus B16

Jumlah Lactobacillus pada kelompok tikus yang diberi asupan $L$. rhamnosus cenderung stabil selama periode pengujian (Gambar 3). Sehari setelah pemberian E. coli K1.1 (H8) tidak terjadi penurunan jumlah Lactobacillus pada feses kelompok tikus yang diberi $L$. rhamnosus (Tabel 4 ). Hal tersebut menunjukkan bahwa pemberian $L$. rhamnosus mampu mempertahankan jumlah Lactobacillus dalam saluran pencernaan walaupun dilakukan pemberian $E$. coli K1.1. Walapun terjadi diare pada kelompok tikus yang diberi $L$. rhamnosus R14 dan $L$. rhamnosus B16, tetapi tidak parah. Probiotik dapat mencegah infeksi bakteri enterik dengan berkompetisi dengan patogen untuk berikatan dengan sel epitel dan meningkatkan respon imun, baik spesifik maupun non-spesifik (Reid et al., 2003; Zanini et al., 2007; Allen et al., 2010). Selain itu, proteksi dari probiotik dalam menghambat bakteri patogen karena probiotik 
menciptakan lingkungan yang tidak sesuai bagi bakteri patogen dan berkompetisi terhadap substrat (Olivares et al., 2006).

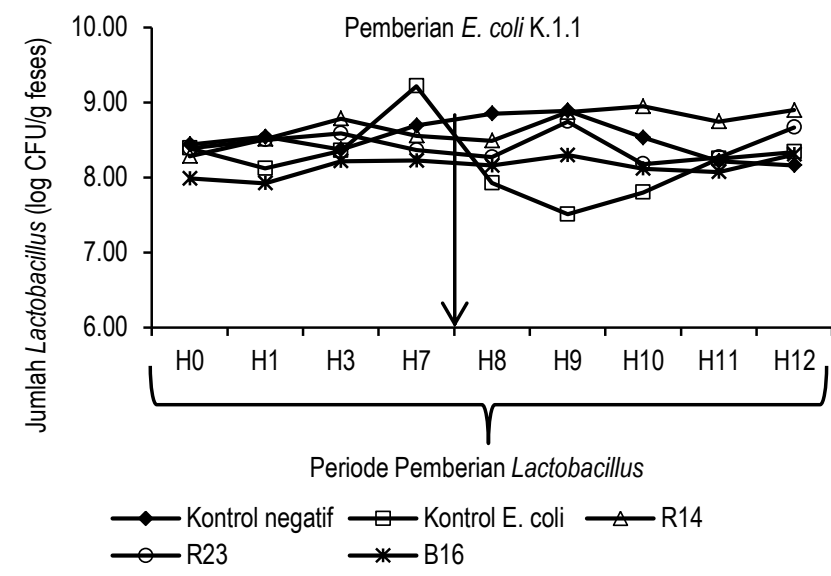

Gambar 3. Jumlah Lactobacillus pada feses tikus pada kelompok kontrol negatif, kontrol $E$. coli, dan kelompok tikus yang diberi L. rhamnosus R14, L. rhamnosus R23, dan $L$. rhamnosus B16

Jumlah $E$. coli dan Lactobacillus pada sekum, kolon dan feses tikus setelah penyembuhan diare

Jumlah E. coli pada sekum, kolon, dan feses setelah tikus melalui masa penyembuhan diare, hampir sama untuk semua perlakuan, yaitu pada sekum antara 7,31-7,94 log CFU/g, pada kolon 7,45-7,72 log CFU/g dan pada feses 7,07-7,90 log CFU/g. Hal yang sama pada jumlah Lactobacillus dalam sekum, kolon dan feses, setelah tikus sembuh dari diare juga tidak menunjukkan perbedaan yang signifikan $(P>0,05)$ antar perlakuan Setelah tikus sembuh dari diare jumlah Lactobacillus pada sekum pada kisaran 8,40-8,64 log CFU/g, pada kolon 8,16-8,56 log CFU/g dan pada feses 8,16-8,90 log CFU/g. Namun demikian, feses kelompok tikus yang diberi $L$. rhamnosus R14 dan $L$. rhamnosus R23 mengandung Lactobacillus yang sedikit lebih tinggi dibandingkan dengan kontrol, yaitu 8,9 log CFU/g untuk $L$. rhamnosus R14 dan 8,67 log CFU/g untuk $L$. rhamnosus R23 dibandingkan dengan kontrol negatif sebesar 8,16 log CFU/g dan kontrol E. coli sebesar 8,34 log CFU/g feses. Sebaliknya, kandungan $E$. coli lebih rendah dari pada kontrol yaitu 7,35 log CFU/g untuk kelompok L. rhamnosus R14 dan 7,12 log CFU/g untuk kelompok L. rhamnosus R23 dibandingkan dengan kontrol negatif sebesar 7,90 log CFU/g dan kontrol $E$. coli sebesar 7,78 log CFU/g feses.

Hasil pengamatan permukaan kolon tikus setelah diterminasi disajikan pada Gambar 4. Pada permukaan kolon tikus yang diberi L. rhamnosus R23 dan R14, tampak cukup banyak bakteri batang pendek yang diduga Lactobacillus, sementara pada kelompok tikus yang hanya diberi $E$. coli didominasi oleh bakteri batang panjang. Berdasarkan pengamatan dengan menggunakan mikroskop, morfologi Lactobacillus berupa batang pendek.

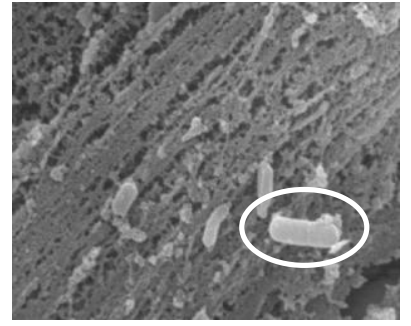

Kontrol Negatif

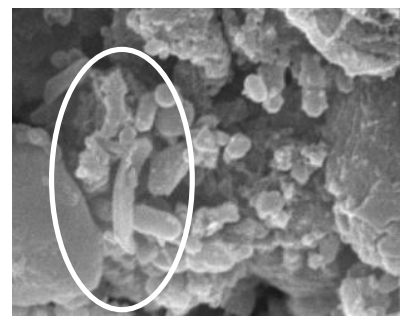

E. coli + R14

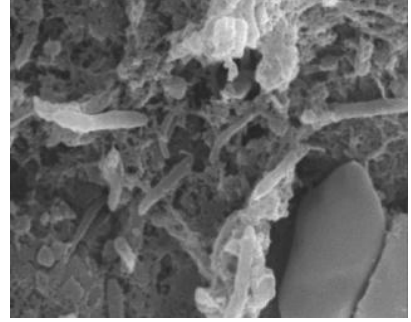

Kontrol E. coli

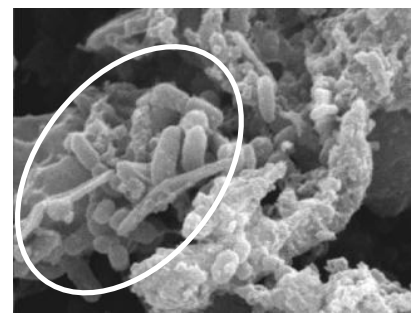

E. colitR23

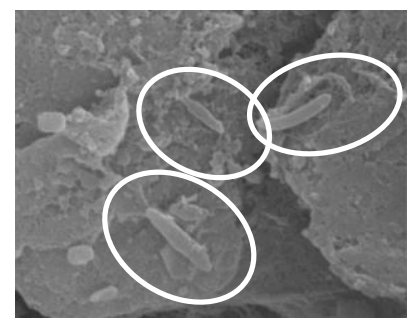

E. colitR23

Keterangan: Bagian gambar yang berada dalam lingkaran putih merupakan bakteri yang diduga sebagai Lactobacillus. R14: L. rhamnosus R14, R23: L. rhamnosus R23, B16: L. rhamnosus B16

Gambar 4. Kondisi mikrobiota kolon tikus pada akhir masa pengujian aktivitas antidiare dengan canning Electron Microscope Model -JSM 5310 LV menggunakan perbesaran 10000x

\section{KESIMPULAN}

Lactobacillus rhamnosus R14, L. rhamnosus R23, dan L. rhamnosus B16 asal ASI menunjukkan aktivitas antimikroba yang baik terhadap $E$. coli enteropatgenik K1.1. Pemberian ketiga isolat Lactobacillus secara reguler berpotensi untuk mencegah terjadinya diare karena infeksi $E$. coli K1.1. Dari ketiga isolat Lactobacillus tersebut $L$. rhamnosus R23 memiliki potensi terbaik untuk mencegah diare dibandingkan kedua isolat $L$. rhamnosus lainnya. L. rhamnosus R23 juga mampu menekan jumlah $E$. coli pada feses segera setelah tikus diberi asupan $E$. coli K1.1. Ketika tikus sudah mengalami masa penyembuhan dari diare, jumlah E. coli dan Lactobacillus pada kelompok tikus yang diberi asupan L. rhamnosus maupun kontrol, tidak berbeda nyata.

\section{UCAPAN TERIMAKASIH}

Penulis menyampaikan terimakasih kepada pihak Direktorat Jenderal Pendidikan Tinggi Departemen Pendidikan Nasional yang telah mendanai penelitian ini melalui program Hibah Kompetitf Penelitian Sesuai Prioritas Nasional Batch II Tahun Anggaran 2009. Penulis juga menyampaikan terimakasih 
kepada Dr. dr. Sri Budiarti dari Laboratorium Bioteknologi Hewan dan Biomedis Pusat Sumberdaya Hayati dan Bioteknologi LPPM IPB, yang telah memberikan koleksi isolat $E$. coli enteropatogenik strain K1.1 sebagai bakteri uji pada penelitian ini.

\section{DAFTAR PUSTAKA}

[AIN] American Institute of Nutrition. 1977. Report of the American Institute of nutrition ad hoc committee on standards for nutritional studies. J Nutr 107: 1340-1348.

Allen SJ, Martinez EG, Gregorio GV, Dans LF. 2010. Probiotics for treating acute infectious diarrhoea. Cochrane Database of Systematic Reviews, Issue 11. Art. No.CD003048. DOI: 10.1002/14651858.CD003048.pub3.

Astawan M, Wresdiyati T, Arief II, Febiyanti D. 2011. Potensi bakteri asam laktat probiotik indigenus sebagai antidiare dan imunomodulator. J Teknol dan Industri Pangan 22: 1116.

Budiarti S, Mubarik NR. 2007. Extracelluler protease activity of enteropathogenic Escherichia coli on mucin substrate. Hayati J Biosciences 14: 36-38.

De Vrese M, Marteau PR. 2007. Probiotics and prebiotics: effects on diarrhea. J Nutr 137: 803S-811S.

[Depkes RI] Departemen Kesehatan Republik Indonesia. 2008. Profil Kesehatan Indonesia 2007. Departemen Kesehatan Republik Indonesia, Jakarta, Indonesia.

[FAO/WHO] Food and Agricultural Organization/World Health Organization. 2002. Guidelines for The Evaluation of Probiotics in Food. London, Ontario, Kanada.

Gueimonde M, Laitinen K, Salminen S, Isolauri E. 2007. Breast milk: A source of Bifidobacteria for infant gut development and maturation? Neonat 92: 64-66. DOI: 10.1159/ 000100088.

Hartanti WH. 2010. Evaluasi Aktivitas Antidiare Isolat Lactobacillus dari Air Susu Ibu. [Tesis]. Sekolah Pasca Sarjana, Institut Pertanian Bogor.

Heyman M, Menard S. 2002. Probiotic microorganism: how they affect intesinal pathophysiology. Cell Mol Life Sci 59: 1-15. DOI: 10.1007/s00018-002-8494-7.

Ishida-Fuji K, Sato R, Goto S, Yang XP, Kuboki H, Hirano SI, Sato M. 2007. Prevention of pathogenic Escherichia coli infection in mice and stimulation of macrophage activation in rats by an oral adminstration of probiotic Lactobacillus casei I-5. Biosci Biotechnol Biochem 71: 866-873. DOI: 10.1271 /bbb.60464.

Lewis SJ, Heaton KW. 1997. Stool form scale as a useful guide to intestinal transit time. Scand J Gastroenterol 32: 920 924. DOI: 10.3109/00365529709011203.

Mandomando IM, Macte EV, Sanz S, Abacassamo F, Valles X, Sacarlal J, Navia MM, Alonso P, Gascon J. 2007. Etiology of diarrhea in children younger tahn 5 years of age admitted in a rural hospital of southern Mozambique. Am J Trop Med Hyg 76: 522-527.

Martin R, Olivares M, Marin LM, Fernandez L. 2005. Probiotic potential of 3 Lactobacilli Strains Isolated from Breast Milk, J of Hum Lactat 21: 18-17. DOI: 10.1177/0890334404272393.
Michail S, Abernathy F. 2002. Lactobacillus plantarum reduces the in vitro secretory response of intestinal epithelial cells to enteropathogenic Escherichia coli infection. J Pediatr Gastroenterol Nutr 35: 350-5. DOI: 10.1097/00005176200209000-00021.

Michail S, Abernathy F. 2003. Lactobacillus plantarum inhibits the intestinal epithelial migration of neutrophils induced by enteropathogenic Escherichia coli. J Pediatr Gastroenterol Nutr 36: 385-391. DOI: 10.1097/00005176-200302000$\underline{00018 .}$

Nguyen RN, Taylor LS, Tauschek M, Robins-Browne RM. 2006. Atypical enteropathogenic Escherichia coli infection and prolonged diarrhea in children. Emerg Infect Dis 12: 597603. DOI: 10.3201/eid1204.051112.

Olivares M, Diaz-Ropero MP, Martin R, Rodriguez JM, Xaus J. 2006. Antimicrobial potential of four Lactobacillus strains isolated from breast milk. J Appl Microbiol 101: 72-79. DOI: 10.1111/j.1365-2672.2006.02981.x.

Oyetayo VO, Adetuyi FC, Akinyosoye FA. 2003. Safety and protective effect of Lactobacillus acidophilus and Lactobacillus casei used as probiotic agent in vivo. Afr $\mathrm{J}$ of Biotechnol 2: 448-452.

Oyetayo VO. 2004. Performance of rats orogastrically dosed with faecal strains of Lactobacillus acidophillus and challenged with Escherichia coli. Afr J of Biotechnol 3: 409411.

Reid G, Jass J, Sebulsky MT, McCormick JK. 2003. Potential Uses of Probiotics in Clinical Practice. Clinical Microbiol. Rev 16: 658-672. DOI: 10.1128/CMR.16.4.658-672.2003.

Sherman PM, Johnson-Herry KC, Yeung HP, Ngo PSC, Goulet J, Tompkins TA. 2005. Probiotics reduce enterohemorrhagic Escherichia coli 0157:H7- and enteropathogenic E. coli 0127:H6-Induced changes in polarized T84 epithelial cell monolayers by reducing bacterial adhesionand cytoskeletal rearrangements. Infection and Immunity 73: 5183-5188. DOI: 10.1128/IAI.73.8.51835188. 2005.

Yatsuyanagi J, Saito S, Miyajima Y, Amano, K, Enomoto, E. 2003. Characterization of atypical enteropathogenic Escherichia coli strains harboring the astA gene that were associated with a waterborne outbreak of diarrhea in Japan. J Clinical Microbiol 41: 2033-2039. DOI: 10.1128/JCM.41.5. 2033-2039.2003.

Zanini K, Marzotto M, Castellazzi A, Borsari A, Dellaglio F, Torriani S. 2007. The effects of fermented milks with simple and complex probiotic mixtures on the intestinal microbiota and immune response of healthy adults and children. Int Dairy J 17: 1332-1343. DOI: 10.1016/i.idairyi.2007.01.017.

Zhang W, Azevedo MSP, Gonzalez AM, Saif LJ, Nguyen TV, Wen K, Yousef AE, Lijuan Yuan L. 2008. Influence of probiotic Lactobacilli colonization on neonatal B cell responses in a gnotobiotic pig model of human rotavirus infection and disease. Vet Immunol Immunopathol 122: 175-181. DOI: 10.1016/j.vetimm.2007.10.003. 